\title{
26. COMPOSITION AND SOURCES OF PUMICES IN LEG 85 CORES 1
}

\author{
Haraldur Sigurdsson and A. N. Davis, Graduate School of Oceanography, University of Rhode Island ${ }^{2}$
}

Pumice and volcanic ash in oceanic sediments can provide indications of wind and ocean current directions in the geologic past. In favorable cases the good stratigraphic control in deep-sea cores can also provide dating of volcanic events in the subaerial volcanic source region if the drilled volcanic deposits can be correlated to the source region. Such correlations can be made on the basis of chemical composition and should ideally involve a large number of elements.

The occurrence of pumice, dispersed volcanic ash, and a few volcanic ash layers in Leg 85 cores indicates that one or more volcanic source regions contributed to this depositional regime. We have studied the composition of pumices from Hole 573B to evaluate their possible source regions. A $10-\mathrm{mm}$ pumice fragment from Section 573B-29-5 $(90-92 \mathrm{~cm})$ occurs in lower Oligocene white chalk. The highly vesicular pumice contains rare microlites of plagioclase. The other pumice fragment studied is $23 \mathrm{~mm}$ in diameter and occurs in lower Miocene brown ooze from Section 573B-15-3 $(56-57 \mathrm{~cm})$. It is a gray, pipe-vesicular pumice that contains rare microphenocrysts of plagioclase.

The composition of the pumice glass was determined by microprobe analysis. The glasses suffered severe sodium loss under the electron beam, and consequently, $\mathrm{Na}$ was determined by the method of Nielsen and Sigurdsson (1981). The average compositions of the two pumices are shown in Table 1, along with standard deviations. The standard deviations are within analytical error, indicating that the pumices are homogeneous. The oxide totals in the microprobe analyses are low for both pumices. We assume that this is an indication of 3-4\% water dissolved in the silicic glass, probably resulting from posteruption hydration.

The glass composition of the two pumices from Hole 573B is markedly different and indicates two contrasting petrographic provinces or source regions. The lower Miocene pumice (Section 573B-15-3) is a quartz trachyte of the type associated with tholeiite-icelandite-quartz trachyte-rhyolite provinces. In the Pacific Ocean such markedly siliceous differentiates are confined to ridge-centered hotspots, such as Easter Island and the Galapagos Islands, lying along the crest of the East Pacific Rise. The lower Miocene pumice (Table 1, column 3) compares rather closely with a siliceous trachyte pumice from the Alcedo Volcano in the Galapagos Islands (Table 1, column 4). The Galapagos Islands may be the source re-

\footnotetext{
${ }^{1}$ Mayer, L., Theyer, F., et al., Init. Repts. DSDP, 85: Washington (U.S. Govt. Printing Office).
2 Address: Graduate School of Oceanography, University of Rhode Island, Kingston, RI 02881 .
}

Table 1. Microprobe analyses of glass in pumices from Site 573, with comparisons.

\begin{tabular}{lrrrr}
\hline & \multicolumn{1}{c}{1} & \multicolumn{1}{c}{2} & \multicolumn{1}{c}{3} & \multicolumn{1}{c}{4} \\
\hline $\mathrm{SiO}_{2}$ & $55.76(0.43)$ & 55.81 & $69.07(0.43)$ & 66.87 \\
$\mathrm{TiO}_{2}$ & $0.43(0.05)$ & 0.26 & $0.30(003)$ & 0.66 \\
$\mathrm{Al}_{2} \mathrm{O}_{3}$ & $22.34(0.20)$ & 22.00 & $12.68(0.22)$ & 12.55 \\
$\mathrm{FeO}^{\mathrm{a}}$ & $2.46(0.06)$ & 2.41 & $4.67(0.26)$ & 4.20 \\
$\mathrm{MgO}$ & $0.22(0.03)$ & 0.21 & $0.14(0.02)$ & 0.60 \\
$\mathrm{MnO}$ & $0.21(0.03)$ & 0.06 & $0.22(0.04)$ & 0.09 \\
$\mathrm{CaO}$ & $2.06(0.10)$ & 0.93 & $1.30(0.04)$ & 1.10 \\
$\mathrm{Na} 2 \mathrm{O}$ & $8.44(0.25)$ & 9.26 & $5.25(0.14)$ & 5.32 \\
$\mathrm{~K}_{2} \mathrm{O}$ & $5.06(0.26)$ & 5.45 & $2.47(0.10)$ & 3.08 \\
& 96.98 & & 96.10 &
\end{tabular}

\begin{tabular}{crrrr} 
Norms & & & & \\
$\mathrm{Q}$ & - & - & 23.73 & 19.79 \\
$\mathrm{Or}$ & 30.83 & 33.41 & 15.19 & 19.27 \\
$\mathrm{Ab}$ & 33.13 & 32.05 & 46.23 & 47.65 \\
$\mathrm{An}$ & 8.38 & 2.46 & 3.89 & 1.34 \\
$\mathrm{Ne}$ & 21.95 & 26.68 & - & - \\
Wo & 0.90 & 0.97 & 1.18 & 1.85 \\
En & 0.11 & 0.12 & 0.36 & 1.58 \\
$\mathrm{Fs}$ & 0.87 & 0.95 & 8.83 & 7.19 \\
Fo & 0.32 & 0.30 & - & - \\
Fa & 2.67 & 2.56 & - & - \\
II & 0.84 & 0.51 & 0.59 & 1.33 \\
\hline
\end{tabular}

Notes: 1. White pumice from Section 573B-29-5, 90-92 cm. Microprobe analysis of glass, average of 10 analyses. Standard deviation in parentheses. 2. Phonolite lava from Tahiti (McBirney and Aoki, 1968). 3. Gray pumice from Section 573B-15-3, $56-57 \mathrm{~cm}$. Microprobe analysis of glass, average of 13 analyses. Standard deviation in parentheses. 4. Siliceous trachyte pumice, Alcedo Volcano, Albemarle Island, Galapagos (McBirney and Williams, 1969).

liams, 1969).
a Total Fe measured as $\mathrm{FeO}$.

gion for the lower Miocene pumice, which is consistent with the Miocene age found for some of the islands themselves (Durham, 1965). An Easter Island source cannot be ruled out on basis of the composition, but the Miocene age is not consistent with the younger age of Easter Island.

The lower Oligocene pumice from Section 573B-29-5 is of phonolitic composition (Table 1, column 1). This phonolite is of the type found in the strongly undersaturated basanite-alkali basalt-phonolite provinces, typical of many offaxis or intraplate oceanic islands. The composition of a phonolite lava from Tahiti is shown for comparison (Table 1, column 2); the two phonolites are virtually identical, except for calcium content. Although Tahiti seems a likely source region for the lower Oligocene phonolite pumice, we cannot rule out other undersaturated volcanic provinces in the region, such as the Marquesas Islands (see Bishop and Woolley, 1983).

The pumice fragments in Leg 85 cores are much too large to have been transported to the site by winds. Thus, no past wind directions can be derived from the presented data. It is more likely that the pumices were transported by surface ocean currents. The petrologic evi- 
dence is consistent with derivation of the lower Miocene pumice from the Galapagos Islands. This is also in agreement with present-day prevailing surface current directions, that is, with the Pacific South Equatorial Current flowing to the west of the Galapagos Islands at a velocity of about 1 knot (Fig. 1). The lower Miocene pumice would have taken about 100 days to reach Site 573 at this drift rate. Derivation of the lower Oligocene pumice by drift in prevailing surface currents from the strongly undersaturated phonolite-producing volcanic islands in the Southern Pacific is highly problematic (Fig. 1). The possible source regions of Marquesas Islands, Tahiti, and Christmas Island all lie upstream of the site within the prevailing summer and winter flow of the Pacific South Equatorial Current. A southerly shift of $5^{\circ}$ latitude of the east-flowing Pacific Equatorial Countercurrent in Oligocene time, however, could account for drift of this pumice from Christmas Island to Site 573. The Equatorial Countercurrent, however, is believed to have developed in early-middle Miocene (15-23 Ma) (Haq, 1981; van Andel et al., 1976) during closing of the Central American Seaway in late Cenozoic time. In light of the postulated absence of the Equatorial Countercurrent in late Oligocene time, transport of the phonolite pumice cannot be attributed to any known Oligocene surface currents from likely sources, and therefore the source of this pumice remains unknown at this time.

\section{REFERENCES}

Bishop, A. C., and Wooley, A. R., 1973. A basalt-trachyte-phonolite series from Ua Pua, Marquesas Islands, Pacific Ocean. Contrib. Miner. Petrol., 39:309-326.

Durham, J. W., 1965. Geology of the Galapagos. Pacific Discovery, 18:3-6.

Haq, B. U., 1981. Paleogene paleoceanography-early Cenozoic oceans revisited. Oceanol. Acta. 4.

McBirney, A. R., and Williams, H., 1969. Geology and petrology of the Galapagos Islands. Mem. Geol. Soc. Am. 118.

Nielsen, C. H., and Sigurdsson, H., 1981. Quantitative methods for electron microprobe analysis of sodium in natural and synthetic glasses. Am. Mineral., 66:547-552.

van Andel, T. H., Heath, G. R., and Moore, T. C., Jr., 1976. Cenozoic history of the central equatorial Pacific: a synthesis based on Deep Sea Drilling Project data. The Geophysics of the Pacific Ocean Basin and its Margins, Geophysical Monogr. Am. Geophys. Union, 19:281-296.

U.S. Navy Marine Climatic Atlas of the World (Vol. V), South Pacific Ocean, 1979. Washington (U.S. Govt. Printing Office).

Date of Initial Receipt: 18 January 1984

Date of Acceptance: 20 January 1984
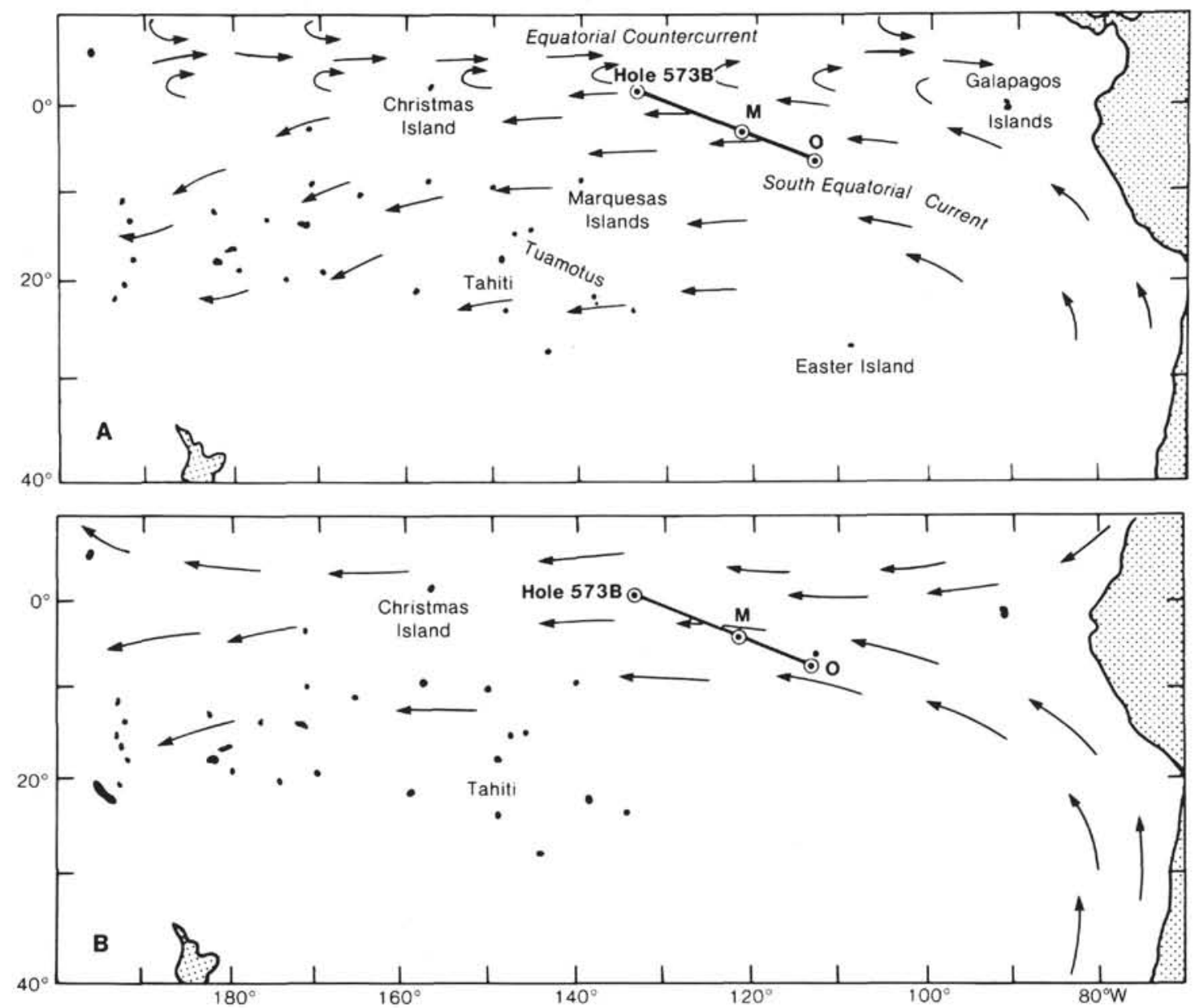

Figure 1. Circulation patterns of surface waters in the equatorial and southern Pacific. A. Present-day winter (June-August) surface currents (U.S. Navy Marine Climatic Atlas of the World, 1979). B. Postulated Oligocene surface currents (35 Ma). Note the open Central American Seaway and the absence of the Equatorial Countercurrent (after Haq, 1981; van Andel et al., 1976). M and O show the back-tracked position of Site 573 in Miocene and Oligocene times, respectively. 